\title{
MICROBIAL ENZYMATIC ACTIVITY AND THERMAL EFFECT IN A TROPICAL SOIL TREATED WITH ORGANIC MATERIALS
}

\author{
Karina Cenciani ${ }^{1}$; Sueli dos Santos Freitas ${ }^{1 *}$; Silvana Auxiliadora Missola Critter $^{1}$; Cláudio \\ Airoldi $^{2}$ \\ ${ }^{1}$ IAC - Centro de Pesquisa e Desenvolvimento de Solos e Recursos Ambientais, C.P. 28 - 13001-970 - Campinas, \\ SP - Brasil. \\ UNICAMP - Instituto de Química, C.P. 6154 - 13084-971 - Campinas, SP - Brasil. \\ *Corresponding author 〈sfreitas@iac.sp.gov.br>
}

\begin{abstract}
Bacteria and fungi are the most active decomposers of organic materials in soil. They directly affect plant nutrient availability, and chemical and physical properties of soils. This investigation aimed at quantifying the effect of several organic materials on microbial activity of a Rhodic Eutrudox. Soil samples were incubated over a period of 91 days with the following organic materials: cattle manure (CM), earthworm humus (HM), and city sewage sludge from Barueri (BA) and Franca (FR). The activities of cellulase, protease and urease enzymes, the soil microbial carbon content (by fumigation-extraction method) and the exothermal effect were evaluated. Experimental design was randomized and arranged as factorial scheme five treatments $\times$ seven samplings with five replications. Organic materials promoted oscillations

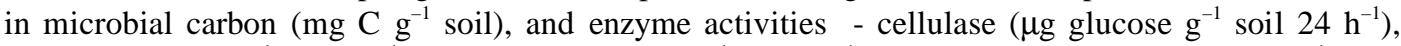
protease $\left(\mathrm{mg} \mathrm{Tyr} \mathrm{g}^{-1}\right.$ soil $\left.2 \mathrm{~h}^{-1}\right)$, urease $\left(\mathrm{mg} \mathrm{NH}_{4}^{+}-\mathrm{N} \mathrm{g}^{-1}\right.$ soil $\left.2 \mathrm{~h}^{-1}\right)$ - and the total thermal effect $\left(\mathrm{J} \mathrm{g}^{-1}\right.$ soil), in the following decreasing order: (1) CM - 21.47; 655.90; 49.68; 24.55; 477.90; (2) BA - 12.98; 367.70; 32.76; 10.66; 426.29; (3) FR - 11.60; 273.40; 18.77; 19.35; 368.00; (4) HM - 11.77; 261.00; 17.05; 9.02; 202.79; (5) control. Correlations were obtained between microbial carbon and cellulase and protease activities $(\mathrm{r}=0.54 ; p<0.001)$, and between the exothermal effect and protease activity $(\mathrm{r}=0.34$; $p<0.005)$. Enzyme activity was closely related to soil microorganisms, therefore, reflecting on the total thermal effect.
\end{abstract}

Key words: enzymes, biomass carbon, organic materials, soil microorganisms, microcalorimetry

\section{ATIVIDADE ENZIMÁTICA DA MICROBIOTA E EFEITO TÉRMICO EMSOLO TROPICAL TRATADO COM COMPOSTOS ORGÂNICOS}

\begin{abstract}
RESUMO: Bactérias e fungos são os organismos mais ativos na decomposição de compostos orgânicos no solo, afetando diretamente a disponibilidade de nutrientes para as plantas e as propriedades químicas e físicas dos solos. Este estudo quantificou o efeito de diversos compostos orgânicos na atividade microbiana de um Latossolo Vermelho Eutroférrico típico. As amostras de solo foram incubadas durante 91 dias sob os tratamentos: esterco bovino (CM), húmus de minhoca (HM), e os lodos de esgoto de Barueri (BA) e Franca (FR). Foram avaliadas as atividades das enzimas celulase, protease e urease, o carbono microbiano do solo (método fumigação-extração) e o efeito exotérmico total. O delineamento experimental foi inteiramente casualizado, em esquema fatorial cinco tratamentos $\times$ sete amostragens com 5 repetições. Os compostos orgânicos promoveram oscilações no carbono microbiano ( $\mathrm{mg} \mathrm{C} \mathrm{g}^{-1}$ solo), na atividade das enzimas celulase $\left(\mu \mathrm{g}\right.$ glicose $\mathrm{g}^{-1}$ solo $24 \mathrm{~h}^{-1}$ ), protease $\left(\mathrm{mg} \mathrm{Tyr} \mathrm{g}{ }^{-1}\right.$ solo $\left.2 \mathrm{~h}^{-1}\right)$ e urease $\left(\mathrm{mg} \mathrm{NH}_{4}^{+}-\mathrm{N} \mathrm{g}^{-1}\right.$ solo $\left.2 \mathrm{~h}^{-1}\right)$ e no efeito térmico total $\left(\mathrm{J} \mathrm{g}^{-1}\right.$ solo), na seguinte ordem decrescente: (1) CM - 21.47; 655.90; 49.68; 24.55; 477.90; (2) BA - 12.98; 367.70; 32.76; 10.66; 426.29; (3) FR - 11.60; 273.40; 18.77; 19.35; 368.00; (4) HM - 11.77; 261.00; 17.05; 9.02; 202.79; (5) controle. Correlações foram obtidas entre o carbono microbiano e as enzimas celulase e protease $(\mathrm{r}=0.54 ; p<0.001)$, e entre o efeito exotérmico e a protease $(\mathrm{r}=0.34 ; p<0.005)$. A atividade de enzimas esteve diretamente relacionada à microbiota do solo, refletindo, dessa forma, no efeito térmico total.

Palavras-chave: enzimas, carbono da biomassa, materiais orgânicos, microrganismos do solo, microcalorimetria
\end{abstract}




\section{INTRODUCTION}

Microorganisms play a major role on decomposition of several organic compounds frequently used in agriculture, which directly affect the synthesis and decomposition of soil organic matter (Carney \& Matson, 2005). Investigations aiming at studying soil organic matter turnover have established the monitoring of microbial enzymes as biochemical parameters (Dinesh et al., 2004).

The main microbial enzymes involved in the mineralization of soil organic matter are cellulases, proteases, ureases and phosphatases (Albiach et al., 2000; Kunito et al., 2001). Cellulase decomposes cellulose compounds present in fresh plant residues that are continuously deposited above soil - the litter layer (Dilly \& Nannipieri, 2001). Nitrogen fertilization is the most important management strategy for the improvement of agricultural crops. Urea is the most widely used source of organic $\mathrm{N}$ fertilizer in the world, which is easily hydrolyzed to ammonium and carbon dioxide by urease enzyme (Masciandaro \& Ceccanti, 1999). Organic nitrogen also affects directly the distribution and action of proteolitic enzymes in soils (Insam, 2001).

The influence of organic materials on microbial biomass and its activity can be monitored by microcalorimetry technique, since any chemical and/or biological reaction is accomplished by heat variations (Prado \& Airoldi, 2001; Núñez-Regueira et al., 2002). It is an useful tool for evaluating the metabolism of microbial biomass in soils (Critter et al., 2004a, b), because it is possible to correlate the heat produced in the various processes with the overall soil metabolism, independently of the organism type and intermediate reactions (Núñez-Regueira et al., 2002).
Accordingly, the objective of our work was to evaluate the influence of some organic amendments, which are of great use in agricultural systems, on soil microbial metabolism by quantifying the activity of some enzymes, microbial carbon content and the total thermal effect.

\section{MATERIAL AND METHODS}

Samples of a clayey-textured Rhodic Eutrudox were collected from a corn cropping farm $\left(22^{\circ} 53^{\prime} \mathrm{S}\right.$, $47^{\circ} 05^{\prime}$ W) near Campinas, State of São Paulo (SP), Brazil, in February 2000. Climate is subtropical, with a wet summer and dry winter (Cwa Koeppen). Soil samples had the top litter layer removed, sieved through a $2 \times 2 \mathrm{~mm}$ mesh screen and dried until constant mass at $378 \mathrm{~K}$ for moisture content determination.

The commercial organic materials used were: manure (CM), earthworm humus (HM) and sewage sludge from Barueri (BA) and Franca (FR) municipal districts, SP, Brazil. They were sieved through a $2 \times 2 \mathrm{~mm}$ screen and added to the soil samples at the proportion of $25 \%$ on a dry mass basis. Five soil replicates were prepared by mixing $25 \mathrm{~g}$ of each organic material to $75 \mathrm{~g}$ of soil. Control replicates (C) were prepared by weighing $100 \mathrm{~g}$ of soil without additions of organic materials. Seven samplings were performed every 15 days during 91 days. Soil samples were stored in open plastic bags moistened every week up to $60 \%$ of water holding capacity (WHC), and maintained in an incubation room at $301 \pm 2 \mathrm{~K}$. Chemical analysis of the soil and organic materials, performed according to Andrade \& Abreu (2006) are on Table 1.

Table 1 - Chemical characteristics of a Rhodic Eutrudox soil and the organic compounds cattle manure, earthworm humus and municipal sewage sludges from Barueri and Franca municipalities.

\begin{tabular}{|c|c|c|c|c|c|c|c|c|c|}
\hline Organic Compounds & Moisture & $\mathrm{C}$ & $\mathrm{N}$ & $\mathrm{P}$ & $\mathrm{K}$ & $\mathrm{Ca}$ & $\mathrm{Mg}$ & $\mathrm{S}$ & $\mathrm{Fe}$ \\
\hline & $\%$ & $-\cdots-1$ & -1 & $\cdots$ & $--\mathrm{g} \mathrm{kg}$ & - & (n- & $-\cdots$ & $-\cdots-\cdots$ \\
\hline Soil & 12.7 & 38 & 1.4 & 1.1 & 1.0 & 0.9 & 0.5 & 0.2 & 131.8 \\
\hline Cattle Manure & 6.6 & 111 & 12.2 & 6.3 & 10.8 & 5.4 & 3.7 & 2.7 & 28.3 \\
\hline Earthworm Humus & 32.8 & 142 & 14.8 & 16.3 & 2.0 & 12.8 & 3.3 & 2.7 & 22.4 \\
\hline Barueri Sludge & 9.7 & 353 & 31.9 & 31.9 & 1.3 & 33.2 & 6.5 & 6.0 & 38.1 \\
\hline Franca Sludge & 10.3 & 411 & 51.1 & 1.9 & 1.9 & 13.3 & 2.2 & 11.9 & 21.7 \\
\hline Organic Compounds & $\begin{array}{c}\mathrm{pH} \\
\left(\mathrm{CaCl}_{2}\right) \\
0.01 \mathrm{~mol} \mathrm{~L}^{-1} \\
\end{array}$ & $\mathrm{Mn}$ & $\mathrm{Zn}$ & $\mathrm{Cd}$ & $\mathrm{Cu}$ & $\mathrm{Cr}$ & $\mathrm{Ni}$ & & $\mathrm{Pb}$ \\
\hline Soil & 5.8 & 500 & 58 & $<0.1$ & 96 & 153.2 & 21.9 & & 46.1 \\
\hline Cattle Manure & 7.3 & 493 & 90 & 0.7 & 79 & 34.1 & 12.2 & & 19.4 \\
\hline Earthworm Humus & 6.2 & 497 & 240 & $<0.1$ & 251 & 26.4 & 12.4 & & 25.4 \\
\hline Barueri Sludge & 12.5 & 502 & 5594 & 35.8 & 1639 & 803 & 724 & & 256 \\
\hline Franca Sludge & 6.0 & 219 & 1418 & 1.3 & 350 & 1072 & 68.2 & & 95.9 \\
\hline
\end{tabular}


Cellulase activity was determined through the measurement of glucose as the final product of cellulose degradation ( $\mu$ g glucose $\mathrm{g}^{-1}$ soil $24 \mathrm{~h}^{-1}$ ) (Hope \& Burns, 1987). Protease activity was obtained through the determination of tyrosine amino acid concentration in the soil samples after incubation with sodium caseinate (mg Tyr g $\mathrm{g}^{-1}$ soil $2 \mathrm{~h}^{-1}$ ) (Ladd \& Butler, 1972). Urease activity was based on the determination of ammonia released after incubation of the soil samples with an urea solution $\left(\mathrm{mg} \mathrm{NH}_{4}^{+}-\mathrm{N} \mathrm{g}^{-1}\right.$ soil $2 \mathrm{~h}^{-1}$ ) (Tabatabai \& Bremner, 1972).

The fumigation-extraction method (Vance et al., 1987) was used to determine soil microbial carbon (mg C g ${ }^{-1}$ soil), extractable in $\mathrm{K}_{2} \mathrm{SO}_{4}$ solution $\left(0.5 \mathrm{~mol} \mathrm{dm}^{-3}\right)$. A thermal activity monitor microcalorimeter, model LKB 2277, Thermometric AB, Sweden, was used for thermal effect measurements. Soil samples $(0.75 \mathrm{~g})$ were mixed with $0.25 \mathrm{~g}$ of organic materials in stainless steel ampoules. An ampoule containing $1.0 \mathrm{~cm}^{3}$ of distilled water was used as reference. Ampoules were hermetically closed and Teflon sealing discs were used to avoid evaporation. Each measurement was run for $1 \mathrm{~h}$ after baseline stabilization. The exothermal effect ( $\mathrm{J} \mathrm{g}^{-1}$ soil) obtained was calculated by the integration of the area under the power curve $(\Delta \mathrm{P} / \mu \mathrm{W})$ versus time $(\Delta \mathrm{t} / \mathrm{s})$.

Experimental design was randomized and arranged as factorial scheme five treatments $\times$ seven samplings with five replications. Treatment effects were statistically evaluated by one-way analysis of variance. Tukey's test was used for mean comparisons at $p \leq 0.05$, and a linear Pearson's correlation analysis was performed in order to correlate the enzyme activities to soil microbial carbon and the exothermal effect.

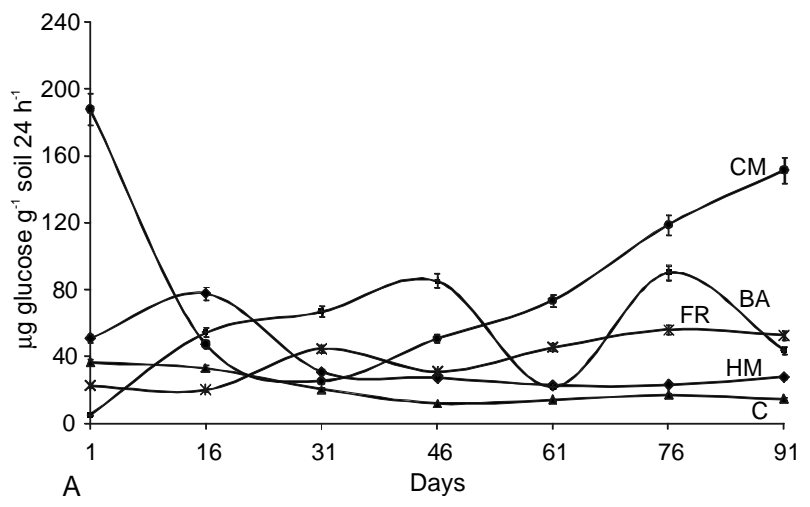

\section{RESULTS AND DISCUSSION}

\section{Enzymes}

The effect of addition of organic materials was strong enough to produce significant results on the activity of enzymes related to carbon and nitrogen cycles (Figures 1-3). The cattle manure treatment yielded the highest levels of nutrient-related enzymatic activities and was different from the other treatments. Cellulase activity increased at the beginning of experiment $\left(188 \mu \mathrm{g}\right.$ glucose $\mathrm{g}^{-1}$ soil $\left.24 \mathrm{~h}^{-1}\right)$, decreased over time reaching a minimum value near the $31^{\text {th }}$ day $(25.5$ $\mu \mathrm{g}$ glucose $\mathrm{g}^{-1}$ soil $24 \mathrm{~h}^{-1}$ ), and after what increased until the last sampling $\left(151.6 \mu \mathrm{g}\right.$ glucose $\mathrm{g}^{-1}$ soil 24 $\mathrm{h}^{-1}$ ) (Figure 1A).

BA sludge increased the microbial production of cellulases around the $45^{\text {th }}$ day $\left(85.2 \mu \mathrm{g}\right.$ glucose $\mathrm{g}^{-1}$ soil $24 \mathrm{~h}^{-1}$ ), followed by subsequent oscillations, when in comparison to FR sludge. Although BA contained higher levels of $\mathrm{Pb}, \mathrm{Ni}, \mathrm{Cd}$ and $\mathrm{Mn}$ than FR (Table $1)$, it seems that metal concentrations were not high enough to inhibit the cellulase activity. Brendecke et al. (1993) found no adverse effect of four years of annual sludge application on microbial activity. The effects of heavy metals on soil enzyme activities are likely to strongly depend on the metal concentrations.

The overall cellulase activity was the lowest in samples treated with HM $\left(261 \mu \mathrm{g}\right.$ glucose $\mathrm{g}^{-1}$ soil $24 \mathrm{~h}^{-1}$ ), but higher than those of unamended control. Such results may be related to the humified composition and stability of the earthworm humus, thus less rich in carbohydrates for soil microorganisms (Pascual et al., 1998). CM also increased the production of proteases (49.68 $\mathrm{mg} \mathrm{Tyr} \mathrm{g}^{-1}$ soil $2 \mathrm{~h}^{-1}$ ) (Figure $2 \mathrm{~B}$ ). Labile nitrogen compounds in $\mathrm{CM}$ have a relatively rapid turnover in soil, thus being readily utilized as a soil microorganisms substrate (Albiach et al., 2000).

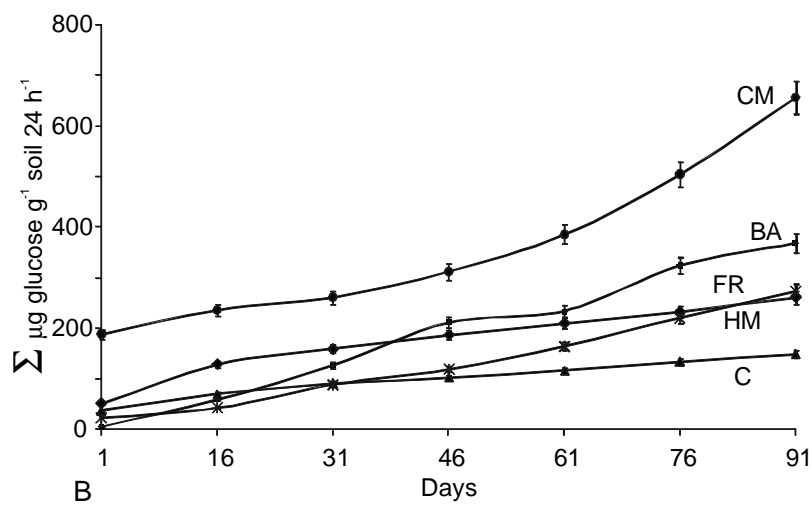

Figure 1 - Cellulase activity ( $\mu$ g glucose $\mathrm{g}^{-1}$ soil $24 \mathrm{~h}^{-1}$ ) (a) and sum of results ( mg glucose $\mathrm{g}^{-1}$ soil $24 \mathrm{~h}^{-1}$ ) (b) in soil samples of a Rhodic Eutrudox $(\mathrm{C})$ amended with cattle manure (CM), earthworm humus (HM) and Barueri (BA) and Franca (FR) sewage sludges during 91 days. 
Barueri and Franca sludge did not present great oscillations in proteolytic activity during the incubation experiment. Therefore, the overall protease activity for BA (32.76 mg Tyr g $\mathrm{g}^{-1}$ soil $2 \mathrm{~h}^{-1}$ ) was higher than in samples treated with HM and FR (17.05 and $18.77 \mathrm{mg}$ Tyr $\mathrm{g}^{-1}$ soil $2 \mathrm{~h}^{-1}$, respectively). This was probably due to a high $\mathrm{pH}$ level of the BA sludge (around 12.5) which contributed to reduce the damaging effect of high metal contents on the microbial enzymatic activity. Heavy metals become unavailable in soils with high $\mathrm{pH}$. Although FR contained the highest total nitrogen value $\left(51 \mathrm{~g} \mathrm{~kg}^{-1}\right)$, microorganisms experienced some difficulty to decompose the complex forms of protein-type nitrogen-containing compounds due to the greater availability of heavy metals (Banerjee et al., 1997).

Microbial production of ureases started lately, around the $76^{\text {th }}$ day (Figure 3A), as compared with cellulase and protease activities. Organic compounds contained small amounts of available urea, as observed in the first sampling. Possibly, a gradual mineralization of nitrogen-rich substrates by proteases released urea as a product from subsequent activity of ureases (Fig-

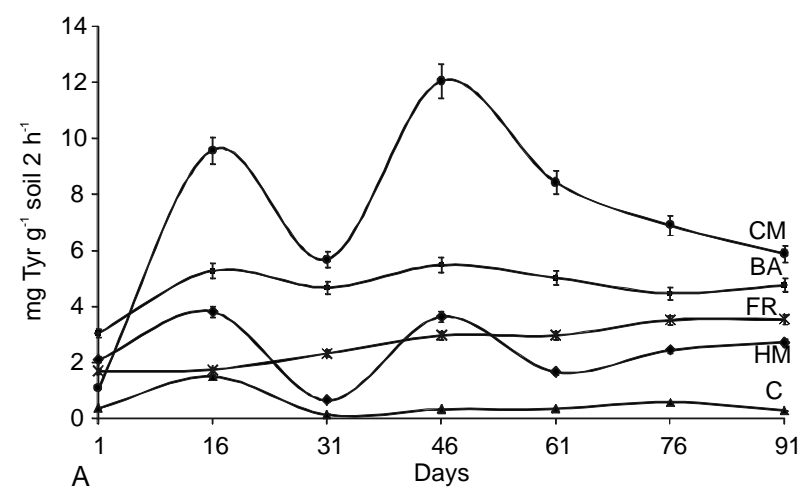

ure 2A) (Masciandaro \& Ceccanti, 1999). CM induced greatest production of ureases along the 91 days ( 24.55

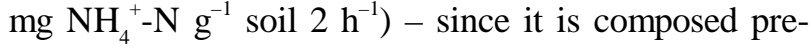
dominantly by urine and solid wastes - (Figure $3 \mathrm{~B}$ ) and as observed earlier for cellulases (Figure 1B) and proteases (Figure 2B).

Franca sludge had higher $\mathrm{NH}_{4}^{+}-\mathrm{N}$ values (19.35 $\mathrm{mg} \mathrm{g}^{-1}$ soil $\left.2 \mathrm{~h}^{-1}\right)$ than BA sludge $(10.66 \mathrm{mg}$ $\mathrm{NH}_{4}^{+}-\mathrm{N} \mathrm{g}^{-1}$ soil $2 \mathrm{~h}^{-1}$ ). This may be because FR sludge had a higher level of substrates able on activating the urease synthesis, thus inhibiting the heavy metals damaging effects (Sastre et al., 1996).

As observed to cellulase and protease enzymes (Figures 1 and 2), urease production in the samples treated with $\mathrm{HM}$ showed the least $\mathrm{NH}_{4}{ }^{+}-\mathrm{N}$ values $\left(9.02 \mathrm{mg} \mathrm{g}^{-1}\right.$ soil $2 \mathrm{~h}^{-1}$ ) suggesting that the complex polymeric composition of $\mathrm{HM}$ are more resistant to decomposition. Bremner \& Mulvaney (1978) and Nannipieri et al. (1996) have reported that humic acids and ureases are closely associated in soils. The enzymatic activity is stabilized when associated to organic and inorganic colloids, acting as a fundamental gateway for extra cellular urease stabilization in soils.

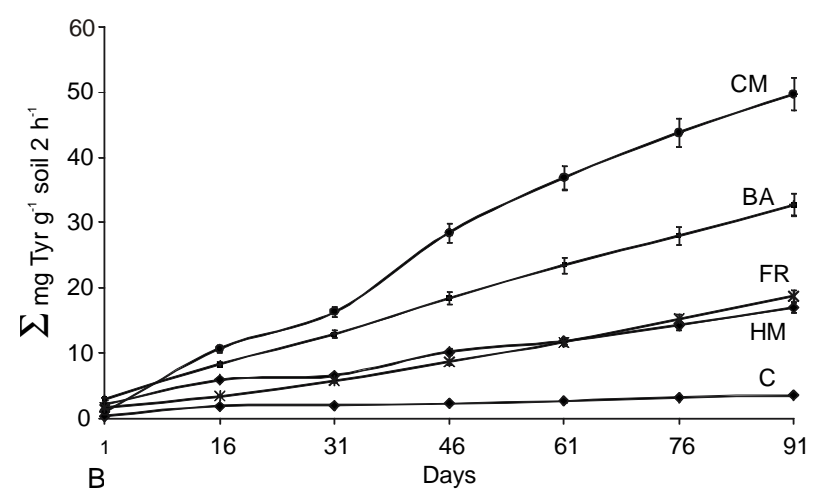

Figure 2 - Protease activity (mg Tyr g $\mathrm{g}^{-1}$ soil $\left.2 \mathrm{~h}^{-1}\right)$ (a) and sum of results $\left(\Sigma \mathrm{mg} \mathrm{Tyr} \mathrm{g}^{-1}\right.$ soil $\left.2 \mathrm{~h}^{-1}\right)$ (b) in soil samples of Rhodic Eutrudox (C) amended with cattle manure (CM), earthworm humus (HM) and Barueri (BA) and Franca (FR) sewage sludges during 91 days.
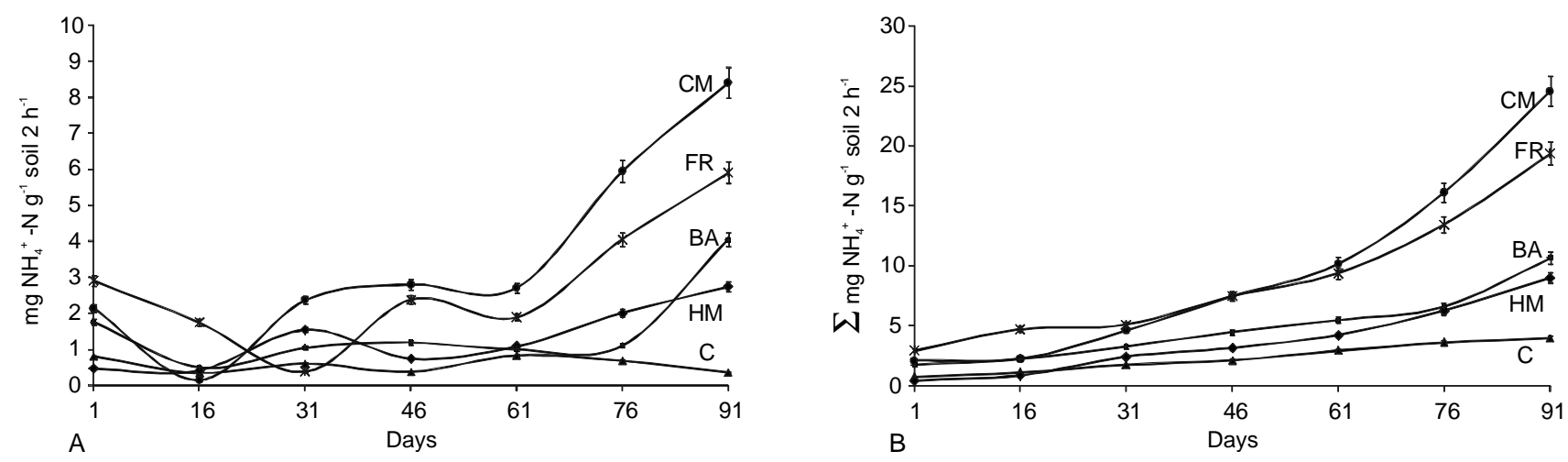

Figure 3 - Urease activity (mg NH${ }_{4}^{+}-\mathrm{N} \mathrm{g}^{-1}$ soil $2 \mathrm{~h}^{-1}$ ) (a) and sum of results $\left(\Sigma \mathrm{mg} \mathrm{NH}_{4}^{+}-\mathrm{N} \mathrm{g}^{-1}\right.$ soil $\left.2 \mathrm{~h}^{-1}\right)$ (b) in soil samples of Rhodic Eutrudox (C) amended with cattle manure (CM), earthworm humus (HM) and Barueri (BA) and Franca (FR) sewage sludges during 91 days. 


\section{Soil Microbial Carbon}

Figure 4A shows experimental treatments effect on the microbial biomass contents in the soil. Large differences were observed owing to a high variability of biochemical composition of the organic materials. At the beginning of the experiment $\mathrm{CM}$ enhanced microbial $\mathrm{C}$ at least twice higher than the other treatments, as expected. The incorporation of easily available compounds in CM activated the soils's autochthonous microorganisms (Pascual et al., 1998). A similar peak of microbial growth was observed around the $46^{\text {th }}$ day for all treatments. Afterwards, microbial carbon decreased in all treatments, and around the $61^{\text {st }}$ day only samples treated with $\mathrm{CM}$ were different from the others (Figure 4A).

Microbial community was more strongly influenced by CM than by BA, FR or EC, which were not different (Figure 4B). Organic treatments stimulated microbial growth and the enzymatic activity due to an enrichment of soil organic matter (Marinari et al., 2000). Soil microbial carbon correlated to cellulase and protease activities $(r=0.54, p<0.001)$ (Table 2), indicating that production of extra cellular enzymes is related to microbial biomass enhancement (Albiach et al., 2000). Cellulase and protease enzymes are good markers of soil biological activity, since they are involved

Table 2 - Pearson's coefficient (r) correlations among enzymatic activity, microbial carbon and microcalorimetric results obtained from a Rhodic Eutrudox soil samples.

\begin{tabular}{lcc}
\hline Parameters & $\begin{array}{c}\text { Microbial } \\
\text { Carbon }\end{array}$ & Microcalorimetry \\
\hline Cellulase & $0.548^{* *}$ & $\mathrm{~ns}$ \\
Protease & $0.547^{* *}$ & $0.346^{*}$ \\
Urease & $\mathrm{ns}$ & $\mathrm{ns}$ \\
Microcalorimetry & $\mathrm{ns}$ & - \\
\hline
\end{tabular}

r: Pearson's coefficient; *: significant at $\alpha<0.05$; **: significant at $\alpha<0.001$; ns: not significant

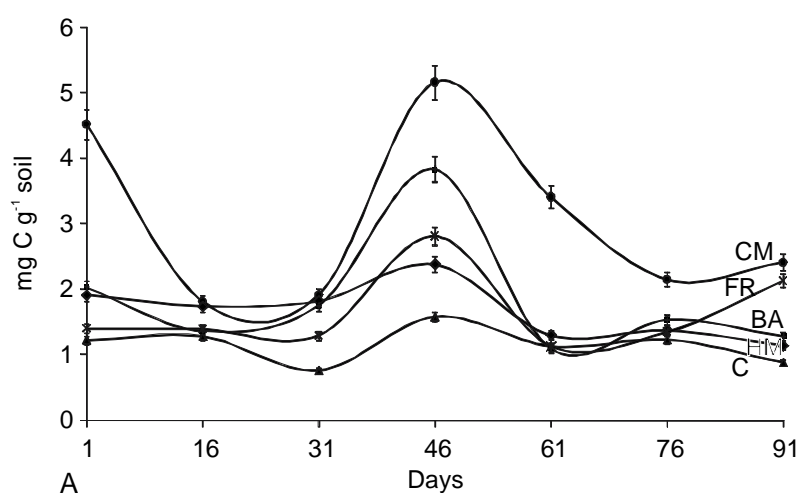

in microbial cycling of nitrogen-rich substrates and cellulose compounds, the most abundant components of organic matter. In turn, the enzymatic activity contributed to higher quantities of microbial C (Dilly \& Nannipieri, 2001).

No correlation was found between microbial $\mathrm{C}$ and urease activity. Increases of urease production around the $76^{\text {th }}$ day (Figure 3A) did not correspond to the period of highest microorganism growth, near the $46^{\text {th }}$ day (Figure 4A). This can be explained by microorganism's rapid ammonium- $\mathrm{N}$ assimilation (consumed or immobilized) before it could be quantified by urease methodology (Masciandaro \& Ceccanti, 1999).

\section{Microcalorimetry}

Typical microcalorimetry power-output curves are reported in Figures 5A (average values) and 5B (cumulative values). Microcalorimetry did not show differences for samples treated with BA, FR or CM. Power time curves were similar, presenting a peak time around the $16^{\text {th }}$ day, that represented the highest recorded microbial activity. Afterwards, thermal effect tended to decrease and stabilize, but beside $31^{\text {th }} \mathrm{CM}$ yet higher heat production was still maintained, followed by BA and FR. All these data approximately represent the different phases of microbial growth - latency, exponential growing, steady phase and decay (Núñez-Regueira et al., 2002).

It was impossible to detect the effect of specific reactions, such as the influence of heavy metals on microbial metabolism for samples treated with city sewage sludges. Total thermal effect can be divided into anabolic (endergonic) and catabolic (exergonic) reactions. In a microcalorimetric system, where microbial growth can be limited by physical factors such as diffusion processes or space, the anabolic enthalpy change is likely to be small as compared to catabolic reactions (Albers et al., 1995).

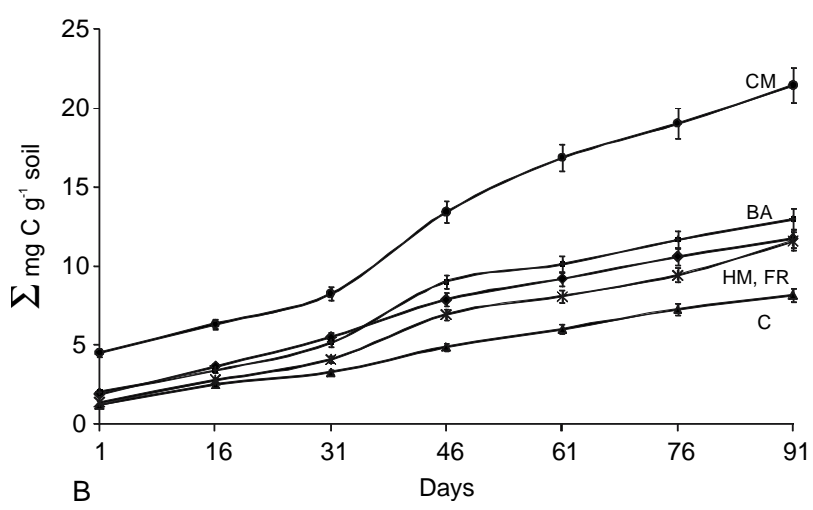

Figure 4 - Microbial biomass carbon ( $\mathrm{mg} \mathrm{C} \mathrm{g}^{-1}$ soil) (a) and sum of results ( $\Sigma \mathrm{mg} \mathrm{C} \mathrm{g}^{-1}$ soil) (b) in soil samples of Rhodic Eutrudox (C) amended with cattle manure (CM), earthworm humus (HM) and Barueri (BA) and Franca (FR) sewage sludges during 91 days. 

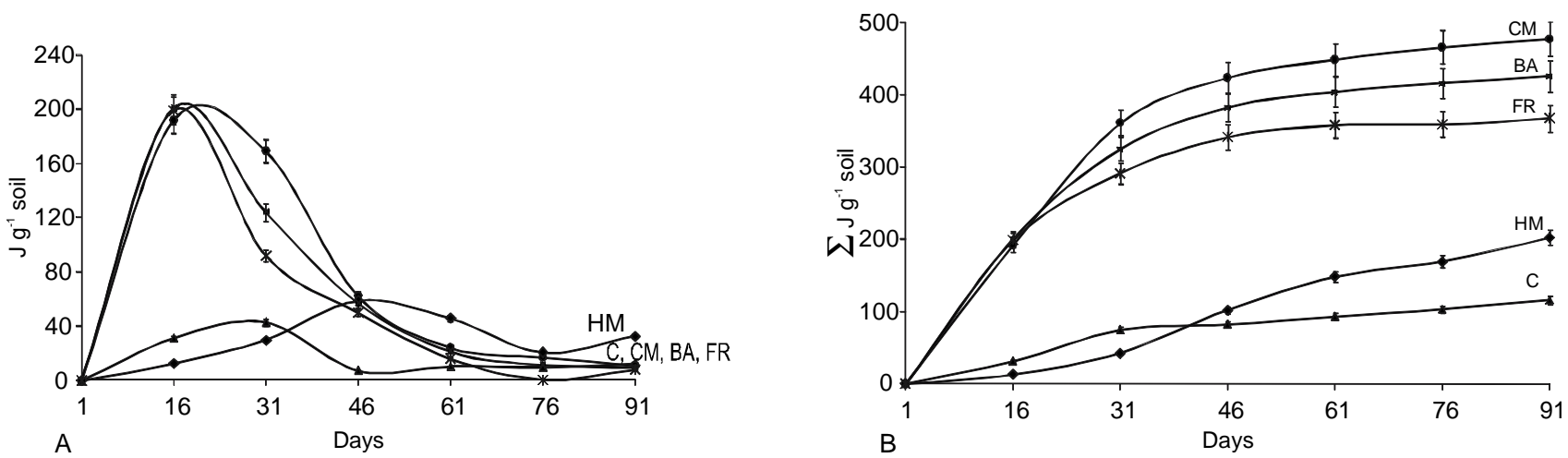

Figure 5 - Exothermic effect ( $\mathrm{J} \mathrm{g}^{-1}$ soil) (a) and sum of results ( $\Sigma \mathrm{J} \mathrm{g}^{-1}$ soil) (b) in soil samples of Rhodic Eutrudox (C) amended with cattle manure (CM), earthworm humus (HM) and Barueri (BA) and Franca (FR) sewage sludges during 91 days.

Earthworm humus contributed to the lowest values of exothermal effect, but above those of the control. Enzyme activities (Figures 1-3) and the soil microbial carbon (Figure 4) showed that microbial activity in the samples treated with HM was smaller. The accumulation of resistant substances, such as humic and fulvic acids, as well labile organic compounds, were previously degraded during the composting process. Therefore, earthworm humus can be an important source of nutrients for microorganisms and plants during long-term periods (Pascual et al., 1998).

Only the protease enzyme was found to be correlated with microcalorimetry measurements. (Table 2). Total thermal effect increased near the $16^{\text {th }}$ day (Figure $2 \mathrm{~A}$, Figure $5 \mathrm{~A}$ ). The peaks representing microbial production of cellulases (Figure 1A) and ureases (Figure $3 \mathrm{~A})$ did not coincide with the values of the exothermal effect. Microbial carbon and the total thermal effect were not also correlated, since microbial $\mathrm{C}$ express only the total amount of carbon retained as microbial biomass, while the total thermal effect reflects the interactive effect of soil biochemical properties plus microbial anabolic and catabolic reactions (Critter et al., 2002).

\section{CONCLUSIONS}

Cattle manure enhanced the production of enzymes, the microbial biomass and the exothermal effect, as well as, but in a lesser degree, the Barueri and Franca sewage sludge. Taking into account the high enzyme sensitivity to the amount of substrate as well as the possible toxic effect of heavy metals, the chemical composition of the organic materials, after it has been added to the soil, may be considered the most important factor influencing on the enzymatic activity. Microcalorimetry shows to be a powerful tool to quantify carbon utilization by soil microorganisms, which in turn leads to a better understanding of the dynamic of soil microbial metabolism.

\section{ACKNOWLEDGMENTS}

To FAPESP for research financial support and a fellowship to Silvana Auxiliadora Missola Critter. To CNPq for a fellowship to Claudio Airoldi; to Dr. R. S. Berton from Laboratory of Soil Fertility (IAC) for the city sewage sludge supply.

\section{REFERENCES}

ALBERS, B.P.; BEESE, F.; HARTMANN, A. Flow-microcalorimetry measurements of aerobic and anaerobic soil microbial activity. Biology and Fertility of Soils, v.19, p.203-208, 1995.

ALBIACH, R.; CANET, R.; POMARES, F.; INGELMO, F. Microbial biomass content and enzymatic activities after the aplication of organic amenments to a horticultural soil. Bioresource Tecnology, v.75, p.43-48, 2000.

ANDRADE, J.C.; ABREU, M.F. Análise Química de Resíduos Sólidos para Monitoramento e Estudos Agroambientais, Editora IAC, Campinas, 2006, 178p.

BANERJEE, M.R.; BURTON, D.L.; DEPOE, S. Impact of sewage sludge application on soil biological characteristics. Agriculture, Ecosystems and Environment, v.66, p.241-249, 1997.

BREMNER, J.M.; MULVANEY, R.L. Urease activity in soils. In: BURNS, R.G. Soil enzymes. London: Academic Press, 1978. p. 149-196.

BRENDECKE, J.W.; AXELSON, R.D.; PEPPER, I.L. Soil microbial activity as an indicator of soil fertility: long-term effects of municipal sewage sludge on an arid soil. Soil Biology and Biochemistry, v.25, p.751-758, 1993.

CARNEY, K.M.; MATSON, P.A. Plant communities, soil microorganisms, and soil carbon cycling: does altering the world belowground matter to ecosystem functioning? Ecosystem, v.8, p.928-940, 2005.

CRITTER, S.A.M.; FREITAS, S.S.; AIROLDI, C. Microbial biomass and microcalorimetric methods in tropical soils. Thermochimica Acta, v.394, p. 145-154, 2002.

CRITTER, S.A.M.; FREITAS, S.S.; AIROLDI, C. Comparison of microbial activity in some Brazilian soils by microcalorimetric and respirometric methods. Thermochimica Acta, v.410, p.3546, 2004a.

CRITTER, S.A.M.; FREITAS, S.S.; AIROLDI, C. Microcalorimetric measurements of the metabolic activity by bacteria and fungi in some Brazilian soils amended with different organic matter. Thermochimica Acta, v.417, p.275-281, 2004b.

DILLY, O.; NANNIPIERI, P. Response of ATP content, respiration rate and enzyme activities in arable and a forest soil to nutrient additions. Biology and Fertility of Soils, v.34, p.34-64, 2001 . 
DINESH, R.; SURYANARAYANA, M.A.; CHAUDHURI, S.G.; SHEEJA, T.E. Long-term of leguminous cover crops on the biochemical properties of a sandy clay loam Fluventic Sulfaquent in a humid tropical region of India. Soil \& Tillage Research, v.77, p.69-77, 2004.

HOPE, C.F.A.; BURNS, R.G. Activity, origin and location of cellulase in a silt loam soil. Biology and Fertility of Soils, v.5, p.164$179,1987$.

INSAM, H. Developments in soil microbiology since the mid 1960s. Geoderma, v. 100, p.389-402, 2001.

KUNITO, T.; SAEKI, K.; GOTO, S.; HAYASHI, H.; OYAIZU, H.; MATSUMOTO, S. Copper and zinc fractions affecting microorganisms in long-term sludge-amended soils. Bioresource Technology, v.79, p.135-146, 2001.

LADD, J.N.; BUTLER, J.H.A. Short-term assays of soil proteolytic enzyme activities using proteins and dipeptide derivatives as substrates. Soil Biology and Biochemistry, v.4, p.19-30, 1972.

MARINARI, S.; MASCIANDARO, G.; CECCANTI, B.; GREGO, S. Influence of organic and mineral fertilisers on soil bilogical and physical properties. Bioresource Technology, v.72, p.9-17, 2000.

MASCIANDARO, G.; CECCANTI, B. Assessing soil quality in different agro- ecosystems through biochemical and chemicostructural properties of humic substances. Soil and Tillage Research, v.51, p.129-137, 1999.

NANNIPIERI, P.; SEQUI, P.; FUSI, P. Humus and enzyme activity. In: PICCOLO, A. (Ed.) Humic substances in terrestrial ecosystems. Amsterdam: Elsevier, 1996. p.293-298.
NÚÑEZ-REGUEIRA, L.; NÚÑEZ-FERNÁNDEZ, O.; AÑÓN, J.A.R.; CASTIÑEIRAS, J.P. The influence of some physicochemical parameters on the microbial growth in soils. Termochimica Acta, v.394, p.123-131, 2002.

PASCUAL, J.A.; HERNANDEZ, T.; GARCIA, C.; AYUSO, M. Enzymatic activities in an arid soil amended with organic wastes: laboratory experiment. Bioresource Technology, v.64, p.131$138,1998$.

PRADO, A.G.S.; AIROLDI, C. Microcalorimetry of the degradation of the herbicide 2,4-D via the microbial population on a typical Brazilian red Latosol soil. Termochimica Acta, v.371, p.169174, 2001.

SASTRE, I.; VICENTE, M.A.; LOBO, M.C. Influence of the aplication of sewage sludges on soil microbial activity. Bioresource Technnology, v.57, p.19-23, 1996.

TABATABAI, M.A.; BREMNER, J.M. Assay of urease activity in soil. Soil Biology and Biochemistry, v.4, p.479-487, 1972.

VANCE, E.D.; BROOKES, P.C.; JENKINSON, D.S. An extraction method for measuring soil microbial biomass C. Soil Biology and Biochemistry, v.19, p. 703-707, 1987.

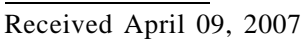

Accepted March 13, 2008 